\title{
STRATEGIC PLANNING OF ORGANIZATIONS ' TRANSITION TO THE SIXTH TECHNOLOGICAL ORDER IN THE NATIONAL ECONOMY
}

\author{
V. V. Glushchenko ${ }^{* 1} \bowtie(i D)$ \\ ${ }^{* 1}$ Doctor of Technical Sciences, Associate Professor, Moscow Polytechnic University, Professor of \\ the Project Activity Center, Moscow, Russia
}

DOI: https://doi.org/10.29121/IJOEST.v5.i1.2021.159

Article Type: Research Article

Article Citation: V. V. Glushchenko. (2021). STRATEGIC PLANNING OF ORGANIZATIONS ' TRANSITION TO THE SIXTH TECHNOLOGICAL ORDER IN THE NATIONAL ECONOMY. International Journal of Engineering Science Technologies, 5(1), 30-46.

https://doi.org/10.29121/IJOEST.v 5.11.2021.159

Received Date: 10 December 2020

Accepted Date: 08 January 2021

Keywords:

System

Analysis

Planning

Strategy

Economy

Technological Structure

Functions

Role

Representation

Properties

Innovations

Elements

\section{ABSTRACT}

The paper discusses the strategic planning of the transition to the sixth technological structure of the economy; the object of the article is the sixth technological order in the national economy; the aim is to increase the effectiveness of strategic planning of development of the sixth technological order in the national economy; to achieve this goal the following tasks: a concept of "technological system"; describes the methodological principles of a scientific theory of technological structures; developed data grid technological structures; synthesized tables of the properties of technological structures; the table is formed of animation technologies of new and previous orders; it formed a methodology for strategic planning of the sixth technological structure; scientifically speaking, strategic planning, algebra, logic, analysis and synthesis, systematic approach, search and normative forecasting, heuristic forecasting, expert methods, logical and comparative analysis; the scientific novelty of the work is determined by the formation of the methodology of strategic planning of the transition of organizations to the sixth technological order in the national economy; the results of the work will be useful for various economic entities (the state, corporations, technology platforms, clusters, innovative firms).

\section{INTRODUCTION}

The relevance of this work is determined by the need to increase the effectiveness of strategic planning for the development of the sixth technological order in the national economy. In addition, it is necessary to take into account the conditions of the economy's exit from the global financial and systemic crisis.

The hypothesis of the article is the statement that in order to increase the efficiency of the development of the sixth technological order in the national economy, it is necessary to develop a methodology for strategic planning of this process in organizations.

(c) 2021 The Author(s). This is an open access article distributed under the terms of the Creative Commons Attribution License, which permits unrestricted use, distribution, and reproduction in any medium, provided the original author and source are credited. 
The purpose of the work is to improve the effectiveness of strategic planning for the development of the sixth technological order in the national economy.

To achieve this goal, the following tasks are solved:

- the concept of "technological structure" has been clarified;

- descriptions of methodological scientific theory of technological orders;

- tables of elements of technological structures are being developed;

- a table of properties of technological structures is synthesized;

- a table of animation technologies of the new and previous styles is being built;

- the methodology of strategic planning for the development of the sixth technological order is being formed.

The object of the article is the sixth technological order in the national economy.

The subject of the article is the strategic planning of the transition of the national economy to the sixth technological order.

The systematic approach is based on the study and consideration of all parts of the technological structure in their mutual connection.

The strategic plan for the development of the sixth technological order in the national economy will be called a system of interrelated long-term measures. These measures are aimed at creating a new technological order in a certain national economy.

We will study scientific publications on the topic of the article. Researchers recognize the need to develop a methodology for strategic planning of the transition to a new technological order [1, p.488-504; 2, p. 2].

There is growing interest in the development of a strategic approach in the country's economy [3, p. 86-91]. Researchers study the conditions of sustainable development in the implementation of strategic plans [4, p. 41-45]. A strategic approach is needed when using the investment resources of organizations [5, p. 69-74]. It is important to develop the human capital of firms [6, p. 84-87].

They design strategic planning tools in the national economy [7, p. 3-8]. They note an increase in the degree of uncertainty of the development conditions in the economy [8, p. 107-110]. The development of strategic plans for the development of business processes is important [9, p. 108-113]. The methodology of strategic planning of innovative development is described in [10, p. 2-4; 11, p. 2-5].

However, the methodology of strategic planning for the development of the sixth technological order in the national economy has not yet been described.

There is a well-known proposal to identify the world economic system with the technological order. The world economic system is defined as a complex of integrated institutions. These institutions form the conditions for the expanded reproduction of capital. Such institutions create the mechanism of world economic relations [12, p. 3-29]. It is difficult to agree with this approach. It is more logical to assume that the global economic order is a geopolitical and macroeconomic "superstructure" over the technological order. The global economic structure reflects the specifics of global institutions in the period of functioning of a certain technological order. Another mistake is the identification of the technological order with the technological basis of the organization, for example, in [13, p. 70-75].

At the same time, the wrong definition of the concept of "technological order" creates risk. This risk can lead to economic damage in the practical implementation of the strategy of transition of the national economy to the sixth technological order.

Only after determining the key concept of "technological order (structure)" (the object of planning) can we proceed to the development of its concept [13, p. 70-75]. The concept of "technological structure (order)" is important when predicting its structure [14, p. 182-189]. This concept is also important in the synthesis of the strategy for the formation of a new way of life in the national economy [15, p.82-89]. It is necessary to study the structural elements of strategic planning of the sixth technological order. They study the conditions for the formation of a new way of life in the economy [16, p. 37-40]. They study the opportunities for the development of the Russian economy in this period [17, p. 54-58]. The analysis of long-term trends of technological progress is carried out [18, p.211-217]. The process of developing a new technological way of life covers the solution of new problems of economic science [19, p. 70-86]. It is necessary to create a new scientific and technical policy of the country [20, p. 201-208]. In strategic planning of the sixth technological order in the national economy, it is recommended to take into account the crisis. The reason for this 
Strategic Planning of Organizations ' Transition to The Sixth Technological Order in The National Economy

crisis is the mismatch between the technological basis and the existing economic institutions [21, p. 24-29]. Therefore, the process of forming a new technological order is simultaneously a process of overcoming their global crisis. When forming a strategic plan for the development of a new technological order, the materials of work on such planning are useful [22, p. 58-61]. In strategic planning, general scientific and private scientific methods are used [23, p. 2]. The strategic plan is based on the scientific theory of technological orders [24, p.60-74]. With such planning, the technological structure appears as a basic factor of the progress of the national economy [25, p. 93-100]. In such planning, the functions and roles of technological order are important [25, p. 80-93].

\section{METHOD}

Under strategic planning, we agree to understand the process of developing a strategic plan for the development of the sixth technological order. The tasks of forming a strategic plan for the formation of the sixth technological order can be considered: external adaptation of the national economy to the structural restructuring of the external environment (world order); internal coordination of the structural segments of the national economy during the time of the sixth technological order. The most common point of view in 2021 is that the technological structure is understood as a set of interrelated production technologies. These technologies should be located at the same technical and technological level. The technologies that make up the way of life develop synchronously [13, p. 70-75]. This interpretation of the concept of "technological way of life" makes this concept equivalent to the concept of the technological basis of the company, industry, economy [24, p. 60-74].

The analysis shows the existence of a systemic relationship between the factors of the world system and the factors of the technological order. The empirical material confirms the broad interrelation of technologies in the national economy, social and economic processes, and institutions. It can be argued that there is an influence of production technologies on: types of money; the world currency system; on the forms and types of business processes in the economy. The technological structure is typical for a certain historical period. This gives grounds to call the system association (aggregation) a" technological way of life".): technological basis, socio-industrial institutions, business processes, management concepts in the economy and society. The technological structure exists at a certain stage of the historical, technological, economic, social, and cultural development of the economy (society).

The theory of technological order can be an effective methodological tool for increasing the efficiency of the processes of creating such a order (structure) in the national economy. In the theory of technological order (structures), the influence of technologies is considered at the following levels: the global system (mega - level); the level of the national economy (macro-level); the level of organizations (legal entities) - the micro-level.

Under the scientific (complete, general) theory of technological order, we will understand the scientific discipline. This scientific discipline is focused on the synthesis of objective knowledge (of a scientific nature) that describes and reflects: the essence of technological order; the influence of technological order on geopolitical, social and economic processes.

Under the scientific method in the scientific theory of technological structures, we will mean a set of principles and techniques. These principles and techniques are used for scientific (objective) knowledge of all types of processes in the new technological order.

The methodological function of the theory of technological structures is the synthesis of concepts, the theoretical basis, the general theory of the method (methodology) of research. These are studies of processes, facts and phenomena that express the essence of the technological order.

The cognitive function of this science is aimed at studying the processes of registration, storage, classification, and analysis of information.

The synthesis of effective methods and programs for the development of the sixth technological order is the instrumental (regulatory) function of the science of technological systems.

The legislative function of this science is to develop the norms of positive law aimed at the development of a new technological order.

The optimization function of the science of technological orders consists in finding optimal options for the development of the sixth technological order.

The predictive function of this scientific theory is to develop probabilistic estimates of the structure and main indicators of the new technological order. 


\section{V. Glushchenko}

The preventive function of the science of technological order lies in the planning and implementation of measures aimed at reducing the magnitude of risks.

The psychological function of the scientific theory of technological order is to form the correct perception of the process of development of a new technological order.

The function of knowledge socialization is to transfer knowledge about the content, essence, and influence of technological orders. This is knowledge about the impact of the technological order on: the world order; the global and national economy; the social environment; the environment; the security of human life and activity in society.

The system-forming function of the science of technological orders consists in the synthesis of the system approach in the process of the formation of the sixth technological order in the economy.

The analysis shows that the science of technological orders performs the following roles:

- increasing the economic efficiency of the policy of developing the structural elements of the technological structure;

- development of the technological structure as a whole;

- reducing risks in the process of forming a new technological order;

- increase in the net present value (NPV) of the investment.

The laws of the scientific theory of technological structures can be considered as:

1) the technological order in the national economy should be understood as the integration into a single whole: a qualitatively new state of the technological basis of organizations; new management methods; new types of business; a new nature of social and industrial relations; new types of transactions;

2) the technological basis (part of the technological structure) is a set of new production and business technologies;

3) the world order is a geopolitical and geo-economic superstructure over the technological order;

4) all technological orders should be studied within the framework of a systematic approach as large, complex humanistic (including human) systems;

5) in the process of developing a new technological way, new technologies are integrated with the technologies of the old technological ways. This leads to the modernization of the technologies of the previous technological orders;

6) the economic efficiency of the technology of the new technological order is determined by the number of integrations (level animation) technology in previous technological orders (the more animations, the higher the economic efficiency of new technologies);

7) in the national economy, a new technological order is born and develops in the depths of the previous technological order. At a certain stage, the existing socio-economic relations (institutions) begin to hinder further development. This leads to a crisis;

8) the systemic crisis of 2008 will subside as a result of the formation of a new technological order. Therefore, the development of a new technological order is an anti-crisis measure.

9) the new technological order represents a qualitative leap in the technological development of the economy.

The laws of the theory of technological structures in mechanical engineering are described in [1, p. 488-504; 2, p. $12-20 ; 26$, p. 80-93].

Methods of the science of technological structures can be: philosophy of science; ideology of management; scientific and technical policy; system approach; analysis and synthesis; heuristic, logical, structural, mathematical forecasting; economic mathematical modeling; sociological methods; methods of cultural studies; management methods; theory of organizational behavior; theories of credit, money, finance; management psychology; theory of state and law; geopolitics.

In this article, the methodology of strategic planning for the development of the sixth technological order in the national economy is formed. This method of strategic planning is part of the predictive function of the scientific theory of technological orders. At the same time, such a technique can also be attributed to the methodological function of the theory of technological orders. 
To synthesize strategic plans for the development of a new technological order in the national economy, an analysis is required. This is an analysis of the elements and properties of the technological order. As a result of such a strategic analysis, it is necessary to describe the technological order as an object of strategic planning.

The essence of the scientific category reveals its functions and roles in social and economic development.

For technological orders, you can recognize the following functions:

- the function of integration into a single system: technological basis; socio-industrial institutions; management methods; business methods; organizational culture;

- the function of the development of industrial relations (institutions) is responsible for the formation of new types of industrial relations (institutions) in society and the economy;

- the function of improving management methods provides a synthesis of new management methods in the economy and society;

- the function of creating a new world order as a new system of international geopolitical relations;

- the function of the development of international monetary and financial relations (institutions);

- the function of creating a new organizational and production culture;

- the function of improving the partnership of the state, society and business [1, p. 488-504; 26, p. 80-93].

At the same time, the technological order performs the following roles:

1) improving the efficiency of public production on the basis of advanced achievements of scientific and technological development;

2) increasing the economic efficiency of investments in new technologies and / or by multiplying technologies;

3) increase the degree of comfort and safety of people's lives.

The strategic analysis of the structure of the technological order can be performed using the functionaldecomposition representation of large systems. Such a representation was proposed in [27, p. 184-186]. Examples of using the functional-decomposition representation for the strategic analysis of elements of technological orders are given in [1, p. 488-504; 2, p. 36-38; 28, p. 44-63; 29-31].

As part of this approach, you can create several tables in the analysis.

The table of elements of the technological sorder (Table No. 1) will have the form of a matrix. The lines of this matrix are designated by the names of all known six technological order of the capitalist period of development. In addition, it is proposed to include two more technological ways in this table. These technological order belong to the pre-capitalist period of development. The technological way of life uses horse-drawn transport (horse traction). It is proposed to call it" -1 "("minus the first") technological order (mode). The second additional pre-capitalist technological order is based on the allocation of a windmill as an energy installation. This technological order (mode) is proposed to be called the "0-m" ("zero") technological order.

The rows of the table of elements of the technological order correspond to the names of technological orders. And the columns of this table are determined by the names of the elements of technological orders. The columns of this table can be: types of power plants (wind, horse-drawn, steam, internal combustion, piston, jet, nuclear, etc.); types of money (gold, credit, electronic cryptocurrencies); type of the world currency system (Paris, Genoa, Breton Woods, Jamaica, etc.); types of characteristic technologies (textile, information, intellectual, etc.); socio-economic formation.

Under the socio-economic formation, we will agree to understand a historically defined type of social structure. This type of social structure is always based on a certain technological order. At the same time, the technological order corresponds to specific: methods of production; methods of management; types of money; production relations. It is customary to distinguish such socio-economic formations: primitive communal; slave-owning, feudal, capitalist, imperialism.

In this strategic analysis, the name of the type of element related to the content of the column is placed at the intersection of the row and column.

An example of a strategic analysis of the structure of the elements of technological order is given in Table No. 1 (Appendix No. 1, on 2 sheets).

Using the second table, you can represent the properties of technological orders. The rows of the second table are similar to the rows of the first table (defined by the name of the layout). The content of the columns of the second table must correspond to the characteristics (properties) of all 8 technological orders accepted for analysis: 
- types of new technological directions;

- main types of products;

- types of money (gold, credit money, electronic money, cryptocurrencies);

- new types of business processes (leasing, factoring, franchising, forfeiting, etc.);

- forms of business organization: manufactories, enterprises, corporations (trusts, consortia, syndicates), virtual corporations, clusters, technology platforms, and more;

- types of production: conveyor, flexible automated production; computer-aided design systems of production, etc.;

- $\quad$ special forms of organization of scientific research;

- forms of competition between producers of goods and / or services: price and non-price competition; competition at the level of goods and services, competition at the level of organizational cultures;

- the fastest growing markets (goods, services, etc.);

- the model of interaction of the organization with the personnel (personnel work, personnel management, human resources management, formation and management of virtual teams, and more);

- the most typical types of organizational structures (functional, product, matrix, etc.).

An example of a strategic analysis of the properties of 8 technological orders is given in Table 2 (Appendix 2, on 2 sheets).

The strategic analysis gives grounds to include in the list of the main directions of development of new technologies: neurotechnologies; nanotechnologies; artificial intelligence technologies; digitalization technologies; information technologies; intelligent technologies; resource-saving technologies; environmentally friendly ("green") technologies and others.

The economic efficiency of the use of new technologies in the economy is determined by the depth and number of integrations (multiplication) of new technologies with the technologies of previous technological orders. The concept of "multiplication (multiplication) of technologies" in this paper will be called the integral characteristic of the number and depth of integration of new and old technologies during the transition to the sixth technological order. The concept of "multiplication (multiplication) of technologies" determines the economic efficiency of the use of new technologies in the national economy of the country.

To study the goals and objectives of such animation of new and old technologies in the period of formation of the new sixth technological order, a third table can be compiled. This is a technology animation table.

Such a table can be developed at two levels: first, at the level of key technologies of previous technological order (macro-level, national economy level); second, at the level of specific products of certain enterprises (micro-economic level). The row numbers of this table can correspond to the numbers of the technological orders. And the columns of this table correspond to the names of the main new technologies of the sixth technological order. At the intersection of the row and column of this table can be enumerated the practical application of the technology, a new way for technological upgrading previous technological order.

The results of drawing up such a table will be useful in shaping the policy of scientific and technological development of the national economy when it enters the sixth technological order. This table allows you to determine the main directions of practical use of new technologies. This use of new technologies leads to an increase in the economic effect of multiplying various technologies. Such multiplication (multiplication) of technologies is useful in the process of modernization of the existing technological basis in the national economy.

An example of such a table is given in Appendix No. 3, Table No. 3.

An example of constructing a table of multiplication of technologies of a new technological way when upgrading the products of a particular enterprise is given in Table No. 4. In this table, the rows correspond to the subsystems of the enterprise's products. In our example, such a product is a vehicle. The columns in Table 4 correspond to the types of new technologies .

Table No. 4 (multiplication of new technologies during vehicle modernization) is given in Appendix No. 4 .

The overall strategic plan for the development of the national economy can cover the development and multiplication of all types of technologies. The development of technologies can be associated with the formation of technological platforms or clusters in the economy. Then private (industry, cluster, etc.) strategic plans can be formed. Each of these plans will cover the development of a separate type of technology (clusters, platforms). Such planning is carried out to the full depth of the technology lifecycle. At the same time, each of the types of strategic plans can contain 
Strategic Planning of Organizations ' Transition to The Sixth Technological Order in The National Economy

two parts (sections). The first part reflects measures to adapt the economy to changes in the external environment (external conditions). And the other part of the strategic plan includes measures to coordinate the internal environment. With such strategic planning, the results of the work can be useful [28, p. 44-63].

\section{DISCUSSION}

A distinctive feature of the formation of the sixth technological order can be considered the presence of a qualitative leap in scientific and technological progress (STP). The presence of a qualitative leap in the NTP limits the possibility of using the analogy. In addition, the existence of a qualitative leap in development prevents the use of statistical methods in such planning.

The next (second) characteristic feature of the synthesis of such a strategic plan can be considered its systematic nature. The systematic nature of the strategic plan is explained by the integration of technical, economic, and organizational parts.

The third special methodological feature of this strategic plan should be recognized that the planning period is equal to the life cycle of technologies in the national economy.

The fourth feature of this plan is that such a strategic plan includes a risk analysis. In addition, it also includes a list of measures to reduce the risks of implementing this plan.

The fifth difference of such a strategic plan is the use of the results of the forecast analysis of the sixth technological order.

The sixth feature of this strategic plan is the need for periodic adjustments to this plan.

The seventh feature of the strategic plan for such development is its flexibility. This means that there is a possibility of making changes to the development goals when the situation in the economy changes.

The strategic plan should take into account the development of innovative activities. Innovation activity will become permanent.

Therefore, it will be necessary to develop new forms of venture financing of innovation activities [32, p. 60-75].

Matrix organizational structures will be further developed and implemented. This is determined by the higher ability of matrix structures to respond to dynamic changes in the external environment. An integral element of the matrix structure is the formation and management of project teams. Often, a project team is created at the stage of project inception. The project team functions throughout the entire project life cycle [33, p. 272-287].

The strategic plan for the development of a new technological order can be recommended to take into account the development of partnership between the state and business. The forms of such partnership can be: state participation in the project; state credit; state subsidies, subsidies, subventions; state guarantees, and others.

The results of the article will be useful for various economic entities (the state, corporations, technology platforms, clusters, innovative firms) in strategic planning.

\section{CONCLUSION}

The article develops the science of technological orders, describes the functions and roles of the scientific theory of technological orders. The article offers methods for analyzing the elements and properties of technological orders. To analyze the structure and properties of technological orders, a functional decomposition representation of complex systems is used. The article describes the features of strategic planning of the transition to the sixth technological order. The principles of strategic planning of the transition to the sixth technological order are justified. The structure and elements of the strategic plan for the transition to the sixth technological order are described. The results of the article will be useful for various economic organizations (government, corporations, technology platforms, clusters, innovative firms) in strategic planning.

Appendix No. 1 Table No. 1: Table of elements of technological orders (beginning)

\begin{tabular}{|c|c|c|c|c|c|}
\hline $\begin{array}{c}\text { № } \\
\Pi / \Pi\end{array}$ & $\begin{array}{l}\text { Elements of } \\
\text { the } \\
\text { technological } \\
\text { order } \\
\text { /Names }\end{array}$ & $\begin{array}{l}\text { Time period } \\
\text { of } \\
\text { Existence } \\
\text { of the }\end{array}$ & $\begin{array}{c}\text { Basic } \\
\text { technological or } \\
\text { propulsion system } \\
\text { of the technological } \\
\text { order }\end{array}$ & $\begin{array}{c}\text { Key types of new products } \\
\text { in the social production of } \\
\text { technological } \\
\text { order }\end{array}$ & $\begin{array}{l}\text { Socio-economic } \\
\text { pharmacy in the } \\
\text { period of the } \\
\text { existence of the }\end{array}$ \\
\hline
\end{tabular}


V. V. Glushchenko

\begin{tabular}{|c|c|c|c|c|c|}
\hline & $\begin{array}{l}\text { technological } \\
\text { order }\end{array}$ & $\begin{array}{l}\text { technological } \\
\text { order }\end{array}$ & & & $\begin{array}{l}\text { technological } \\
\text { order }\end{array}$ \\
\hline \multirow[t]{9}{*}{ (1) } & (2) & (3) & (4) & (5) & (6) \\
\hline & $\begin{array}{c}\text { "-1" } \\
\text { technological } \\
\text { order } \\
\text { (structure) }\end{array}$ & $\begin{array}{l}2000 \mathrm{BC}- \\
9 \text { th century } \\
\text { AD }\end{array}$ & $\begin{array}{l}\text { Horse-drawn } \\
\text { (horse-drawn) } \\
\text { traction }\end{array}$ & $\begin{array}{l}\text { Agricultural products, } \\
\text { transport services }\end{array}$ & $\begin{array}{c}\text { Social-tribal } \\
\text { system, slave- } \\
\text { owning system }\end{array}$ \\
\hline & $\begin{array}{l}\text { "0" } \\
\text { technological } \\
\text { order }\end{array}$ & $\begin{array}{c}\text { 9th century } \\
\text { AD- } \\
1770\end{array}$ & $\begin{array}{l}\text { Windmill } \\
\text { (windmill) and } \\
\text { water mill }\end{array}$ & $\begin{array}{l}\text { Flour and other processed } \\
\text { agricultural products }\end{array}$ & $\begin{array}{l}\text { Slaveholding, } \\
\text { feudalism }\end{array}$ \\
\hline & $\begin{array}{c}\text { The first } \\
\text { technological } \\
\text { order }\end{array}$ & $1770-1830$ & textile machinery & $\begin{array}{l}\text { Machine-made fabrics, } \\
\text { manufactory products }\end{array}$ & $\begin{array}{l}\text { Feudalism, } \\
\text { capitalism }\end{array}$ \\
\hline & $\begin{array}{l}\text { The second } \\
\text { technological } \\
\text { order (way of } \\
\text { life) }\end{array}$ & $1830-1880$ & steam engine & $\begin{array}{l}\text { Metal products as a result of } \\
\text { mechanical processing }\end{array}$ & $\begin{array}{l}\text { Feudalism, } \\
\text { capitalism }\end{array}$ \\
\hline & $\begin{array}{c}\text { The third } \\
\text { technological } \\
\text { order }\end{array}$ & $1880-1930$ & electric motor & $\begin{array}{l}\text { Locomotives, airplanes, } \\
\text { telephone, telegraph }\end{array}$ & imperialism \\
\hline & $\begin{array}{c}\text { The fourth } \\
\text { technological } \\
\text { order }\end{array}$ & $1930-1970$ & $\begin{array}{c}\text { internal } \\
\text { combustion engine }\end{array}$ & $\begin{array}{l}\text { Cars, diesel locomotives, } \\
\text { airplanes, washing machines, } \\
\text { refrigerators,televisions }\end{array}$ & imperialism \\
\hline & $\begin{array}{c}\text { The fifth } \\
\text { technological } \\
\text { order }\end{array}$ & $1970-2010$ & microelectronics & $\begin{array}{l}\text { Flexible automated } \\
\text { manufacturing, cell phones, } \\
\text { plastic bank cards }\end{array}$ & globalism \\
\hline & $\begin{array}{l}\text { Sixth } \\
\text { technological } \\
\text { order }\end{array}$ & $2010-2040$ & nanotechnology & $\begin{array}{l}\text { 3-D printing products, } \\
\text { information products, } \\
\text { transformation of human } \\
\text { thinking (clip thinking) }\end{array}$ & globalism \\
\hline
\end{tabular}

Source: developed by the author

Appendix No. 1. Table No. 1: Table of elements of technological structures (continued, end)

\begin{tabular}{|c|c|c|c|c|c|}
\hline $\begin{array}{c}\text { № } \\
\text { П/ח }\end{array}$ & $\begin{array}{c}\text { Type of } \\
\text { international } \\
\text { monetary system }\end{array}$ & $\begin{array}{c}\text { The form of the } \\
\text { state, political } \\
\text { syst }\end{array}$ & $\begin{array}{c}\text { Manufacturing } \\
\text { enterprises }\end{array}$ & $\begin{array}{l}\text { Key types of public } \\
\text { production technologies }\end{array}$ & $\begin{array}{c}\text { Structure and } \\
\text { characteristics of } \\
\text { labor }\end{array}$ \\
\hline \multirow[t]{5}{*}{$(1)$} & (7) & (8) & (9) & $(10)$ & $(11)$ \\
\hline & $\begin{array}{c}\text { Individual products } \\
\text { that act as an } \\
\text { equivalent }\end{array}$ & $\begin{array}{l}\text { Communities, } \\
\text { community- } \\
\text { generic }\end{array}$ & Gender & $\begin{array}{c}\text { transport and agricultural } \\
\text { technologies }\end{array}$ & $\begin{array}{l}\text { simple abstract } \\
\text { work }\end{array}$ \\
\hline & $\begin{array}{c}\text { Gold as a universal } \\
\text { equivalent }\end{array}$ & principalities & $\begin{array}{l}\text { Family, clan, } \\
\text { craftsman, }\end{array}$ & $\begin{array}{l}\text { Mechanized processing } \\
\text { technologies }\end{array}$ & $\begin{array}{c}\text { simple abstract } \\
\text { work }\end{array}$ \\
\hline & $\begin{array}{c}\text { Gold as a universal } \\
\text { equivalent }\end{array}$ & $\begin{array}{l}\text { Empires, } \\
\text { monarchies }\end{array}$ & $\begin{array}{l}\text { Manufactories, } \\
\text { factories, }\end{array}$ & $\begin{array}{c}\text { Technologies of } \\
\text { mechanized textile } \\
\text { production }\end{array}$ & $\begin{array}{l}\text { simple abstract } \\
\text { work }\end{array}$ \\
\hline & $\begin{array}{l}\text { Paris currency } \\
\text { system, full-fledged } \\
\text { (gold) money }\end{array}$ & $\begin{array}{l}\text { Empires, } \\
\text { monarchies }\end{array}$ & $\begin{array}{l}\text { International } \\
\text { monopolies }\end{array}$ & $\begin{array}{l}\text { Mechanized } \\
\text { metalworking } \\
\text { technologies }\end{array}$ & $\begin{array}{l}\text { simple abstract } \\
\text { work }\end{array}$ \\
\hline
\end{tabular}


Strategic Planning of Organizations ' Transition to The Sixth Technological Order in The National Economy

\begin{tabular}{|c|c|c|c|c|}
\hline $\begin{array}{l}\text { gold-currency } \\
\text { system, three } \\
\text { international } \\
\text { currency blocks, } \\
\text { credit money } \\
\end{array}$ & $\begin{array}{l}\text { National States, } \\
\text { the Republic of }\end{array}$ & $\begin{array}{l}\text { Multinational } \\
\text { corporations, }\end{array}$ & $\begin{array}{l}\text { Technologies of electric } \\
\text { welding of metals, } \\
\text { mechanical processing }\end{array}$ & $\begin{array}{c}\text { special } \\
\text { knowledge and } \\
\text { skills } \\
\text { (competencies) }\end{array}$ \\
\hline $\begin{array}{c}\text { gold-currency } \\
\text { system, } \\
\text { international } \\
\text { Bretton Woods } \\
\text { monetary system, } \\
\text { credit money } \\
\end{array}$ & $\begin{array}{l}\text { States, military- } \\
\text { political blocs, } \\
\text { bipolar world }\end{array}$ & $\begin{array}{l}\text { Multinational } \\
\text { corporations, }\end{array}$ & $\begin{array}{c}\text { Technology of execution } \\
\text { of works, machining } \\
\text { equipment }\end{array}$ & $\begin{array}{c}\text { special } \\
\text { knowledge and } \\
\text { skills } \\
\text { (competencies) }\end{array}$ \\
\hline $\begin{array}{c}\text { demonetization of } \\
\text { gold, the Jamaican } \\
\text { monetary system, } \\
\text { electronic and } \\
\text { digital money }\end{array}$ & $\begin{array}{c}\text { States, trade } \\
\text { and economic } \\
\text { blocs, } \\
\text { Global unipolar } \\
\text { world }\end{array}$ & $\begin{array}{l}\text { Multinational } \\
\text { corporations, } \\
\text { virtual } \\
\text { corporations, }\end{array}$ & $\begin{array}{l}\text { Flexible automated } \\
\text { technologies, } \\
\text { technologies for the } \\
\text { production of trace } \\
\text { elements and printed } \\
\text { circuit boards }\end{array}$ & $\begin{array}{c}\text { competencies, } \\
\text { intellectual } \\
\text { capital }\end{array}$ \\
\hline $\begin{array}{l}\text { international } \\
\text { cryptocurrency } \\
\text { system, virtual, } \\
\text { technological } \\
\text { money }\end{array}$ & $\begin{array}{c}\text { States, trade } \\
\text { and economic } \\
\text { blocks, virtual } \\
\text { blocks of states, } \\
\text { A global } \\
\text { multipolar } \\
\text { world }\end{array}$ & $\begin{array}{c}\text { Clusters, } \\
\text { technology } \\
\text { platforms, global } \\
\text { information } \\
\text { systems, }\end{array}$ & $\begin{array}{c}\text { Nanotechnologies, } \\
\text { nanotechnologies, } \\
\text { information technologies, } \\
\text { digitalization } \\
\text { technologies, resource- } \\
\text { saving and } \\
\text { environmentally friendly } \\
\text { technologies }\end{array}$ & $\begin{array}{c}\text { competencies, } \\
\text { intellectual } \\
\text { capital }\end{array}$ \\
\hline
\end{tabular}

Source: developed by the author

Appendix No.2. Table No. 2: Table of properties of technological structures (beginning)

\begin{tabular}{|c|c|c|c|c|c|}
\hline $\begin{array}{c}\text { № } \\
\text { П/П }\end{array}$ & $\begin{array}{l}\text { Properties of } \\
\text { Technological } \\
\text { orders } \\
\text { /Names } \\
\text { Technological } \\
\text { orders }\end{array}$ & $\begin{array}{l}\text { Time period, } \\
\text { Base } \\
\text { technology, the } \\
\text { propulsion } \\
\text { system }\end{array}$ & $\begin{array}{l}\text { New types of } \\
\text { production }\end{array}$ & $\begin{array}{l}\text { The most } \\
\text { intensively } \\
\text { developing segment } \\
\text { of the economy, } \\
\text { new types of } \\
\text { business processes }\end{array}$ & $\begin{array}{c}\text { Types of } \\
\text { technologies, scale of } \\
\text { production }\end{array}$ \\
\hline \multirow[t]{5}{*}{$(1)$} & (2) & (3) & (4) & (5) & (6) \\
\hline & $\begin{array}{c}\text { «-1» } \\
\text { Technological } \\
\text { order }\end{array}$ & $\begin{array}{c}2000 \mathrm{BC}- \\
9 \text { th century AD, } \\
\text { horse- } \\
\text { drawn traction }\end{array}$ & $\begin{array}{c}\text { Horse-drawn } \\
\text { transport services }\end{array}$ & $\begin{array}{c}\text { Agriculture, Bill } \\
\text { circulation, money } \\
\text { changers }\end{array}$ & $\begin{array}{l}\text { Manual single and } \\
\text { small-scale } \\
\text { production }\end{array}$ \\
\hline & $\begin{array}{c}\ll 0 » \\
\text { Technological } \\
\text { order }\end{array}$ & $\begin{array}{l}\text { 9th century- } \\
1770 \\
\text { Windmill( } \\
\text { windmill), a } \\
\text { water mill } \\
\end{array}$ & $\begin{array}{l}\text { Mechanized flour- } \\
\text { milling production } \\
\text { based on wind and } \\
\text { water energy }\end{array}$ & $\begin{array}{l}\text { Agriculture, } \\
\text { Promissory note } \\
\text { circulation }\end{array}$ & $\begin{array}{l}\text { Manual single and } \\
\text { small-scale } \\
\text { production }\end{array}$ \\
\hline & $\begin{array}{c}\text { The first } \\
\text { technological } \\
\text { order (way of } \\
\text { life) }\end{array}$ & $\begin{array}{l}\text { 1770-1830, } \\
\text { Textile } \\
\text { Machinery }\end{array}$ & $\begin{array}{l}\text { Mechanized textile } \\
\text { production }\end{array}$ & $\begin{array}{c}\text { Industrial } \\
\text { production, Bank } \\
\text { settlements and } \\
\text { payments }\end{array}$ & $\begin{array}{l}\text { Machine serial } \\
\text { production }\end{array}$ \\
\hline & $\begin{array}{c}\text { The second } \\
\text { technological } \\
\text { order }\end{array}$ & $\begin{array}{l}\text { 1830-1880, } \\
\text { Steam engine }\end{array}$ & $\begin{array}{c}\text { Mechanized } \\
\text { mechanical } \\
\text { processing and } \\
\end{array}$ & $\begin{array}{l}\text { Industrial } \\
\text { production, } \\
\text { factoring }\end{array}$ & $\begin{array}{l}\text { Machine serial } \\
\text { production }\end{array}$ \\
\hline
\end{tabular}




\section{V. Glushchenko}

\begin{tabular}{|c|c|c|c|c|}
\hline & & $\begin{array}{c}\text { transport services } \\
\text { based on the steam } \\
\text { engine }\end{array}$ & & \\
\hline $\begin{array}{c}\text { The third } \\
\text { technological } \\
\text { orders (mode) }\end{array}$ & $\begin{array}{c}\text { 1880-1930, } \\
\text { Electric motor }\end{array}$ & $\begin{array}{c}\text { Mechanized } \\
\text { mechanical } \\
\text { processing and } \\
\text { transport services } \\
\text { based on an electric } \\
\text { motor } \\
\end{array}$ & $\begin{array}{l}\text { Industrial } \\
\text { production, } \\
\text { factoring }\end{array}$ & $\begin{array}{c}\text { Конвейрное } \\
\text { крупносерийное } \\
\text { производство }\end{array}$ \\
\hline $\begin{array}{l}\text { The fourth } \\
\text { technological } \\
\text { order }\end{array}$ & $\begin{array}{l}\text { 1930-1970, } \\
\text { Internal } \\
\text { combustion } \\
\text { engine }\end{array}$ & $\begin{array}{l}\text { Automated } \\
\text { production facilities } \\
\text { and transport services } \\
\text { based on the internal } \\
\text { combustion engine }\end{array}$ & $\begin{array}{c}\text { Industrial } \\
\text { production, leasing }\end{array}$ & $\begin{array}{c}\text { Mass automated } \\
\text { production }\end{array}$ \\
\hline $\begin{array}{c}\text { The fifth } \\
\text { technological } \\
\text { order }\end{array}$ & $\begin{array}{c}\text { 1970-2010, } \\
\text { microelectronics }\end{array}$ & $\begin{array}{c}\text { Automated } \\
\text { production of trace } \\
\text { elements and printed } \\
\text { circuit boards, } \\
\text { microprocessor } \\
\text { devices }\end{array}$ & $\begin{array}{l}\text { Service sector, } \\
\text { Franchising, } \\
\text { forfeiting, } \\
\text { online trading }\end{array}$ & $\begin{array}{l}\text { Flexible automated } \\
\text { production facilities }\end{array}$ \\
\hline $\begin{array}{c}\text { Sixth } \\
\text { technological } \\
\text { order }\end{array}$ & $\begin{array}{c}\text { 2010-2040, } \\
\text { nanotechnology }\end{array}$ & $\begin{array}{c}\text { Production of } \\
\text { materials with } \\
\text { specified properties, } \\
\text { nanotechnological } \\
\text { production, } \\
\text { environmentally } \\
\text { friendly production }\end{array}$ & $\begin{array}{l}\text { Service sector, } \\
\text { Online settlements, } \\
\text { online trading, } \\
\text { cross-border } \\
\text { settlements in } \\
\text { cryptocurrencies }\end{array}$ & $\begin{array}{l}\text { Technologies for the } \\
\text { production of } \\
\text { materials with } \\
\text { specified properties, } \\
\text { the transformation of } \\
\text { human thinking }\end{array}$ \\
\hline
\end{tabular}

Source: developed by the author

Appendix No.2. Table No. 2: Properties of technological structures (Continued)

\begin{tabular}{|c|c|c|c|c|c|}
\hline $\begin{array}{l}\text { № } \\
\Pi / \Pi\end{array}$ & $\begin{array}{c}\text { Properties of } \\
\text { Technological } \\
\text { orders } \\
\text { /Names } \\
\text { Technological } \\
\text { orders }\end{array}$ & $\begin{array}{l}\text { The time period } \\
\text { of the } \\
\text { existence of } \\
\text { technological } \\
\text { orders }\end{array}$ & $\begin{array}{c}\text { Technologies, } \\
\text { methods and scale } \\
\text { of production, labor }\end{array}$ & $\begin{array}{c}\text { Экономическая } \\
\text { политика, Виды } \\
\text { организационных } \\
\text { структур }\end{array}$ & $\begin{array}{c}\text { Концепции } \\
\text { управления, работы } \\
\text { с персоналом }\end{array}$ \\
\hline \multirow[t]{4}{*}{ (1) } & (2) & (3) & (7) & (8) & (9) \\
\hline & $\begin{array}{c}"-1 " \\
\text { technological } \\
\text { order } \\
\text { (structure) }\end{array}$ & $\begin{array}{l}2000 \text { BC- } \\
\text { 9th century AD, } \\
\text { Horse traction }\end{array}$ & $\begin{array}{l}\text { Technologies of } \\
\text { manual single and } \\
\text { small-scale } \\
\text { production, simple } \\
\text { abstract work }\end{array}$ & $\begin{array}{l}\text { Informal economic } \\
\text { policy, traditional } \\
\text { organizational } \\
\text { structures }\end{array}$ & $\begin{array}{l}\text { Centralization, } \\
\text { organization, control, } \\
\text { labor promotion, } \\
\text { management as an art, } \\
\text { unity of command, } \\
\text { human relations }\end{array}$ \\
\hline & $\begin{array}{c}0 " \\
\text { technological } \\
\text { order } \\
\text { (structure) }\end{array}$ & $\begin{array}{l}\text { 9th century- } \\
1770 \\
\text { Windmill( } \\
\text { Windmill), a } \\
\text { water mill }\end{array}$ & $\begin{array}{l}\text { Technologies of } \\
\text { manual single and } \\
\text { small-scale } \\
\text { production, simple } \\
\text { abstract work }\end{array}$ & $\begin{array}{l}\text { Informal economic } \\
\text { policy, Traditional } \\
\text { organizational } \\
\text { structures }\end{array}$ & $\begin{array}{l}\text { Formation of } \\
\text { requirements for the } \\
\text { manager, the theory of } \\
\text { power, the study of } \\
\text { the impact of } \\
\text { automation }\end{array}$ \\
\hline & $\begin{array}{c}\text { The first } \\
\text { technological }\end{array}$ & $\begin{array}{l}\text { 1770-1830, } \\
\text { Textile } \\
\text { Machinery }\end{array}$ & $\begin{array}{c}\text { Mechanized } \\
\text { technologies of } \\
\text { mass production, }\end{array}$ & $\begin{array}{l}\text { Informal economic } \\
\text { policy, Traditional }\end{array}$ & $\begin{array}{l}\text { Economic theory, } \\
\text { financial theory, the } \\
\text { principle of }\end{array}$ \\
\hline
\end{tabular}


Strategic Planning of Organizations ' Transition to The Sixth Technological Order in The National Economy

\begin{tabular}{|c|c|c|c|c|}
\hline $\begin{array}{l}\text { order (way of } \\
\text { life) }\end{array}$ & & $\begin{array}{c}\text { simple abstract } \\
\text { work }\end{array}$ & $\begin{array}{l}\text { organizational } \\
\text { structures }\end{array}$ & $\begin{array}{c}\text { specialization of } \\
\text { industrial workers }\end{array}$ \\
\hline $\begin{array}{l}\text { The second } \\
\text { technological } \\
\text { order (way of } \\
\text { life) }\end{array}$ & $\begin{array}{l}\text { 1830-1880, } \\
\text { Steam engine }\end{array}$ & $\begin{array}{c}\text { Mechanized } \\
\text { technologies of } \\
\text { machine-building } \\
\text { mass production, } \\
\text { simple abstract } \\
\text { work }\end{array}$ & $\begin{array}{l}\text { Informal economic } \\
\text { policy, Traditional } \\
\text { organizational } \\
\text { structures }\end{array}$ & $\begin{array}{l}\text { The theory of public } \\
\text { services, the analysis } \\
\text { of motivation of } \\
\text { employees }\end{array}$ \\
\hline $\begin{array}{c}\text { The third } \\
\text { technological } \\
\text { order (mode) }\end{array}$ & $\begin{array}{c}\text { 1880-1930, } \\
\text { Electric motor }\end{array}$ & $\begin{array}{l}\text { Technologies of } \\
\text { large-scale } \\
\text { conveyor } \\
\text { production, special } \\
\text { management and } \\
\text { labor skills } \\
\end{array}$ & $\begin{array}{l}\text { Approved economic } \\
\text { and industrial } \\
\text { policies, Functional } \\
\text { organizational } \\
\text { structures }\end{array}$ & $\begin{array}{c}\text { Scientific } \\
\text { management, methods } \\
\text { of statistics in } \\
\text { management, } \\
\text { personnel work }\end{array}$ \\
\hline $\begin{array}{c}\text { The fourth } \\
\text { technological } \\
\text { order }\end{array}$ & $\begin{array}{l}\text { 1930-1970, } \\
\text { Internal } \\
\text { combustion } \\
\text { engine }\end{array}$ & $\begin{array}{l}\text { Technologies of } \\
\text { automated large- } \\
\text { scale production, } \\
\text { job descriptions }\end{array}$ & $\begin{array}{l}\text { Approved economic } \\
\text { and industrial policy, } \\
\text { strategic } \\
\text { management, } \\
\text { product } \\
\text { organizational } \\
\text { structures }\end{array}$ & $\begin{array}{l}\text { Operational research, } \\
\text { system analysis, } \\
\text { marketing, program- } \\
\text { target approach, } \\
\text { personnel } \\
\text { management, } \\
\text { personnel motivation } \\
\text { systems }\end{array}$ \\
\hline $\begin{array}{c}\text { The fifth } \\
\text { technological } \\
\text { order }\end{array}$ & $\begin{array}{c}\text { 1970-2010, } \\
\text { microelectronics }\end{array}$ & $\begin{array}{l}\text { Flexible automated, } \\
\text { production, } \\
\text { competence cards } \\
\text { and qualification } \\
\text { cards }\end{array}$ & $\begin{array}{l}\text { Approved innovation } \\
\text { policy, matrix } \\
\text { organizational } \\
\text { structures, clusters, } \\
\text { technology platforms }\end{array}$ & $\begin{array}{l}\text { Project approach, } \\
\text { post-industrial } \\
\text { marketing, } \\
\text { participatory } \\
\text { management, human } \\
\text { resource management }\end{array}$ \\
\hline $\begin{array}{c}\text { Sixth } \\
\text { technological } \\
\text { order }\end{array}$ & $\begin{array}{c}\text { 2010-2040, } \\
\text { nanotechnology }\end{array}$ & $\begin{array}{l}\text { Nanotechnology, } \\
\text { nanotechnology, } \\
\text { information } \\
\text { technology, the } \\
\text { study and } \\
\text { transformation of } \\
\text { the properties of } \\
\text { materials and } \\
\text { human thinking }\end{array}$ & $\begin{array}{l}\text { Approved innovation } \\
\text { policy, } \\
\text { Organizational } \\
\text { architecture, design, } \\
\text { culture }\end{array}$ & $\begin{array}{c}\text { Theory of } \\
\text { technological } \\
\text { structures, project } \\
\text { approach } \\
\text { neuromanagement, } \\
\text { neuromarketing, } \\
\text { management of social } \\
\text { development of } \\
\text { personnel, project } \\
\text { education }\end{array}$ \\
\hline
\end{tabular}

Source: developed by the author

Appendix No. 2. Table No.2: Table of properties of technological orders (structures) (End)

\begin{tabular}{|c|c|c|c|c|c|}
\hline $\begin{array}{c}\text { № } \\
\Pi / \Pi\end{array}$ & $\begin{array}{c}\text { Human rights, } \\
\text { family relations }\end{array}$ & $\begin{array}{c}\text { Hierarchy in } \\
\text { society, the elite of } \\
\text { society }\end{array}$ & $\begin{array}{c}\text { Types of higher } \\
\text { education } \\
\text { institutions, }\end{array}$ & $\begin{array}{c}\text { the } \\
\text { higher } \\
\text { education } \\
\text { model }\end{array}$ & $\begin{array}{c}\text { Organizational forms of } \\
\text { science and innovation }\end{array}$ \\
\hline$(1)$ & $(7)$ & $(8)$ & $(9)$ & $(10)$ & $(11)$ \\
\hline 1. & $\begin{array}{c}\text { Equality of } \\
\text { members of the } \\
\text { genus, family- } \\
\text { genus }\end{array}$ & $\begin{array}{c}\text { A classless society, } \\
\text { the elite is elected } \\
\text { by the clan }\end{array}$ & $\begin{array}{c}\text { Teaching in the } \\
\text { home }\end{array}$ & $\begin{array}{c}\text { Teaching in the } \\
\text { home }\end{array}$ & $\begin{array}{c}\text { Research, innovation in } \\
\text { the genus, family }\end{array}$ \\
\hline 2. & $\begin{array}{c}\text { Slaves and } \\
\text { slaveholders, }\end{array}$ & $\begin{array}{c}\text { Class society, elite } \\
\text { princes and the }\end{array}$ & $\begin{array}{c}\text { Teaching in the } \\
\text { home }\end{array}$ & $\begin{array}{c}\text { Teaching in the } \\
\text { home }\end{array}$ & $\begin{array}{c}\text { Research, innovation in } \\
\text { the genus, family }\end{array}$ \\
\hline
\end{tabular}


V. V. Glushchenko

\begin{tabular}{|c|c|c|c|c|c|}
\hline & $\begin{array}{l}\text { serfs and } \\
\text { landowners, } \\
\text { monogamous } \\
\text { family }\end{array}$ & $\begin{array}{c}\text { prince's retinue, } \\
\text { nobles }\end{array}$ & & & \\
\hline 3. & $\begin{array}{l}\text { Property } \\
\text { inequality of } \\
\text { rights, } \\
\text { monogamous } \\
\text { family }\end{array}$ & $\begin{array}{c}\text { Class society, a } \\
\text { hereditary elite of } \\
\text { the feudal lords and } \\
\text { capitalists }\end{array}$ & $\begin{array}{l}\text { Universities, } \\
\text { vocational } \\
\text { schools }\end{array}$ & $\begin{array}{c}\text { Subject higher } \\
\text { education }\end{array}$ & $\begin{array}{l}\text { Science and innovation in } \\
\text { universities, academies of } \\
\text { sciences }\end{array}$ \\
\hline 4. & $\begin{array}{l}\text { Property } \\
\text { inequality of } \\
\text { rights, } \\
\text { monogamous } \\
\text { family }\end{array}$ & $\begin{array}{l}\text { Class society, a } \\
\text { hereditary elite of } \\
\text { capitalists }\end{array}$ & $\begin{array}{l}\text { Universities, } \\
\text { Technological } \\
\text { institutes }\end{array}$ & $\begin{array}{c}\text { Subject higher } \\
\text { education }\end{array}$ & $\begin{array}{l}\text { Science and innovation in } \\
\text { technological institutes, } \\
\text { academies of sciences }\end{array}$ \\
\hline 5. & $\begin{array}{l}\text { Property } \\
\text { inequality of } \\
\text { rights, } \\
\text { monogamous } \\
\text { family }\end{array}$ & $\begin{array}{l}\text { Class society, elite- } \\
\text { hereditary } \\
\text { capitalists }\end{array}$ & $\begin{array}{l}\text { Universities, } \\
\text { Technological } \\
\text { institutes }\end{array}$ & $\begin{array}{l}\text { Subject higher } \\
\text { education }\end{array}$ & $\begin{array}{c}\text { Наука и инновации в } \\
\text { технологических } \\
\text { институтах, научно- } \\
\text { исследовательских } \\
\text { институтах, академиях } \\
\text { наук } \\
\end{array}$ \\
\hline 6. & $\begin{array}{c}\text { Universal } \\
\text { Declaration of } \\
\text { Human Rights, } \\
\text { equality of } \\
\text { rights, } \\
\text { monogamous } \\
\text { family } \\
\end{array}$ & $\begin{array}{l}\text { Class society, elite- } \\
\text { hereditary } \\
\text { capitalists }\end{array}$ & $\begin{array}{c}\text { Universities, } \\
\text { Technological } \\
\text { institutes }\end{array}$ & $\begin{array}{l}\text { Subject higher } \\
\text { education } \\
\text { Education, } \\
\text { integration of } \\
\text { science and } \\
\text { education }\end{array}$ & $\begin{array}{c}\text { Research and production } \\
\text { associations, } \\
\text { experimental design } \\
\text { bureaus }\end{array}$ \\
\hline 7. & $\begin{array}{l}\text { equality of } \\
\text { rights, } \\
\text { monogamous } \\
\text { family, «sexual } \\
\text { revolution» }\end{array}$ & $\begin{array}{l}\text { Class society, elite- } \\
\text { capitalists who } \\
\text { made their own } \\
\text { fortune, innovators, } \\
\text { cultural figures }\end{array}$ & $\begin{array}{l}\text { Universities, } \\
\text { educational } \\
\text { platforms, } \\
\text { globalization of } \\
\text { education }\end{array}$ & $\begin{array}{l}\text { Competence- } \\
\text { based higher } \\
\text { education, } \\
\text { distance } \\
\text { "smart" } \\
\text { education }\end{array}$ & $\begin{array}{l}\text { Research departments } \\
\text { within global } \\
\text { corporations }\end{array}$ \\
\hline 8. & $\begin{array}{l}\text { equality of } \\
\text { rights, } \\
\text { civil } \\
\text { partnerships }\end{array}$ & $\begin{array}{l}\text { Class society, elite- } \\
\text { capitalists who } \\
\text { made their own } \\
\text { fortune, innovators, } \\
\text { internetocracy } \\
\text { (netocracy) }\end{array}$ & $\begin{array}{l}\text { Universities, } \\
\text { university entry } \\
\text { into clusters and } \\
\text { technology } \\
\text { platforms }\end{array}$ & $\begin{array}{l}\text { Project-based } \\
\text { higher } \\
\text { education, } \\
\text { distance } \\
\text { education, } \\
\text { integration of } \\
\text { science, practice } \\
\text { and education }\end{array}$ & $\begin{array}{l}\text { Scientific and } \\
\text { technological platforms, } \\
\text { research laboratories }\end{array}$ \\
\hline
\end{tabular}

Source: developed by the author

Appendix No. 3. Table 3: Objectives of animation of the key technologies of the sixth technological mode with the technologies of the previous technological modes

\begin{tabular}{|c|c|c|c|c|c|}
\hline № & $\begin{array}{c}\text { Technologies of } \\
\text { п/п }\end{array}$ & Nanotechnology & of nanotehnologii & Information & Technologies of \\
thechnological & & & & \\
terder & & & & \\
& $\begin{array}{c}\text { digitalization } \\
\text { Technos, period } \\
\text { order }\end{array}$ & & & & \\
\hline
\end{tabular}


Strategic Planning of Organizations ' Transition to The Sixth Technological Order in The National Economy

\begin{tabular}{|c|c|c|c|c|c|}
\hline (1) & (2) & (3) & (4) & (5) & (6) \\
\hline 1. & $\begin{array}{l}\text { "-1" technological } \\
\text { order, } \\
2000 \mathrm{BC}- \\
\text { 9th century AD, } \\
\text { Horse- } \\
\text { drawn (horse- } \\
\text { drawn) traction }\end{array}$ & $\begin{array}{l}\text { Strengthening of } \\
\text { cart materials, } \\
\text { improving the } \\
\text { quality of paint }\end{array}$ & $\begin{array}{l}\text { Registration of the } \\
\text { psychophysical state } \\
\text { of the draft animal } \\
\text { and the driver }\end{array}$ & $\begin{array}{l}\text { Informing the } \\
\text { driver about the } \\
\text { condition of the } \\
\text { draft animal }\end{array}$ & $\begin{array}{l}\text { Registration and } \\
\text { recording of the } \\
\text { conditions of the } \\
\text { draft animal and } \\
\text { the driver }\end{array}$ \\
\hline 2. & $\begin{array}{c}\text { "0" technological } \\
\text { order, } \\
9 \text { th century- } \\
1770, \\
\text { Windmill( } \\
\text { windmill), a } \\
\text { water mill } \\
\end{array}$ & $\begin{array}{l}\text { Strengthening the } \\
\text { materials of } \\
\text { windmills and mills, } \\
\text { improving the } \\
\text { quality of paint }\end{array}$ & $\begin{array}{l}\text { Registration of the } \\
\text { psychophysical state } \\
\text { of mill workers }\end{array}$ & $\begin{array}{l}\text { Informing mill } \\
\text { workers about } \\
\text { their operating } \\
\text { modes, loads, etc. }\end{array}$ & $\begin{array}{l}\text { Registration of } \\
\text { information } \\
\text { about the } \\
\text { operating modes } \\
\text { of a windmill, } \\
\text { windmill, etc. }\end{array}$ \\
\hline 3. & $\begin{array}{c}\text { The first } \\
\text { technological } \\
\text { order, } \\
\text { 1770-1830, } \\
\text { Textile Machinery }\end{array}$ & $\begin{array}{c}\text { Strengthening of } \\
\text { materials of fabrics } \\
\text { and textile } \\
\text { machines, } \\
\text { improving the } \\
\text { quality of paint }\end{array}$ & $\begin{array}{l}\text { Registration of the } \\
\text { psychophysical state } \\
\text { of weavers, } \\
\text { registration of } \\
\text { buyers ' reactions to } \\
\text { various fabrics }\end{array}$ & $\begin{array}{l}\text { Optimization of the } \\
\text { loom operation } \\
\text { process, selection } \\
\text { of patterns and } \\
\text { colors, informing } \\
\text { weavers about } \\
\text { shift tasks and } \\
\text { resources }\end{array}$ & $\begin{array}{l}\text { Recording the } \\
\text { operating modes } \\
\text { of the loom, } \\
\text { recording the } \\
\text { consumption of } \\
\text { fabric, paints, and } \\
\text { electricity in } \\
\text { production }\end{array}$ \\
\hline 4. & $\begin{array}{c}\text { The second } \\
\text { technological } \\
\text { order, } \\
\text { 1830-1880, } \\
\text { Steam engine }\end{array}$ & $\begin{array}{l}\text { Strengthening the } \\
\text { materials of steam } \\
\text { engine parts, } \\
\text { improving the } \\
\text { quality of paint }\end{array}$ & $\begin{array}{l}\text { Registration of the } \\
\text { psychophysical state } \\
\text { of the operator, } \\
\text { registration of the } \\
\text { reactions of others } \\
\text { to various modes of } \\
\text { operation of the } \\
\text { engine }\end{array}$ & $\begin{array}{l}\text { Optimization of the } \\
\text { steam engine } \\
\text { operation process, } \\
\text { informing the } \\
\text { operator about the } \\
\text { safety of the } \\
\text { operating mode, } \\
\text { resource } \\
\text { consumption }\end{array}$ & $\begin{array}{l}\text { Digital recording } \\
\text { of steam engine } \\
\text { operating modes } \\
\text { and operator } \\
\text { control actions }\end{array}$ \\
\hline 5. & $\begin{array}{c}\text { The Third } \\
\text { technological } \\
\text { order, } \\
\text { 1880-1930, } \\
\text { Electric motor }\end{array}$ & $\begin{array}{l}\text { Strengthening the } \\
\text { materials of electric } \\
\text { motor parts, } \\
\text { improving the } \\
\text { quality of paint }\end{array}$ & $\begin{array}{c}\text { fixing the } \\
\text { psychophysical state } \\
\text { of the operator, } \\
\text { registering the } \\
\text { reactions of others } \\
\text { to various modes of } \\
\text { operation }\end{array}$ & $\begin{array}{l}\text { Optimization of the } \\
\text { electric motor } \\
\text { operation process, } \\
\text { informing the } \\
\text { operator about the } \\
\text { safety of the } \\
\text { operating mode, } \\
\text { resource } \\
\text { consumption }\end{array}$ & $\begin{array}{l}\text { Digital recording } \\
\text { operation modes } \\
\text { of the electric } \\
\text { motor and the } \\
\text { control actions of } \\
\text { the operator }\end{array}$ \\
\hline 6. & $\begin{array}{l}\text { Fourth } \\
\text { technological } \\
\text { order, } \\
\text { 1930-1970, } \\
\text { Internal } \\
\text { combustion } \\
\text { engine }\end{array}$ & $\begin{array}{l}\text { Strengthening the } \\
\text { materials of internal } \\
\text { combustion engine } \\
\text { parts, improving the } \\
\text { quality of paint }\end{array}$ & $\begin{array}{l}\text { Registration of the } \\
\text { psychophysical state } \\
\text { of the engine } \\
\text { operator, } \\
\text { registration of the } \\
\text { reactions of others } \\
\text { to various modes of } \\
\text { operation }\end{array}$ & $\begin{array}{l}\text { Optimization of the } \\
\text { internal } \\
\text { combustion engine } \\
\text { operation process, } \\
\text { informing the } \\
\text { operator about the } \\
\text { safety of the } \\
\text { operating mode, } \\
\text { resource } \\
\text { consumption }\end{array}$ & $\begin{array}{l}\text { Digital recording } \\
\text { of internal } \\
\text { combustion } \\
\text { engine operating } \\
\text { modes and } \\
\text { operator control } \\
\text { actions }\end{array}$ \\
\hline
\end{tabular}


V. V. Glushchenko

\begin{tabular}{|c|c|c|c|c|c|}
\hline 7. & $\begin{array}{c}\text { The fifth } \\
\text { technological } \\
\text { order, } \\
1970-2010, \\
\text { microelectronics }\end{array}$ & $\begin{array}{c}\text { The creation of } \\
\text { microelectronics } \\
\text { with desired } \\
\text { qualities }\end{array}$ & $\begin{array}{c}\text { Fixing the } \\
\text { psychophysical state } \\
\text { of the production } \\
\text { operator, the } \\
\text { reactions of others } \\
\text { to the various modes } \\
\text { of operation of the } \\
\text { plant }\end{array}$ & $\begin{array}{c}\text { Optimization of the } \\
\text { production process } \\
\text { of trace elements, } \\
\text { informing the } \\
\text { operator about the } \\
\text { safety of the } \\
\text { operating mode, } \\
\text { resource } \\
\text { consumption }\end{array}$ & $\begin{array}{c}\text { The digital } \\
\text { recording of the } \\
\text { modes of } \\
\text { production of } \\
\text { trace elements, } \\
\text { control } \\
\text { commands and } \\
\text { effects operator }\end{array}$ \\
\hline
\end{tabular}

Source: developed by the author

Appendix No. 4. Table No. 4: Table of multiplication of technologies in the modification of vehicles (TS) during the transition to the sixth technological order

\begin{tabular}{|c|c|c|c|c|c|}
\hline $\begin{array}{c}\text { № } \\
\text { П/П }\end{array}$ & $\begin{array}{c}\text { Technologies of } \\
\text { the sixth order } \\
\text { /Names } \\
\text { of vehicle } \\
\text { subsystems }\end{array}$ & nanotechnology & of nanotehnologii & $\begin{array}{l}\text { Information } \\
\text { technology }\end{array}$ & $\begin{array}{l}\text { Resource-saving } \\
\text { technologies }\end{array}$ \\
\hline \multirow[t]{5}{*}{$(1)$} & (2) & (3) & (4) & (5) & (6) \\
\hline & Vehicle housing & $\begin{array}{l}\text { Increasing the } \\
\text { strength of the body } \\
\text { parts of the vehicle, } \\
\text { increasing the wear } \\
\text { resistance of the paint }\end{array}$ & $\begin{array}{c}\text { Registration of } \\
\text { human reactions } \\
\text { and identification of } \\
\text { the most dangerous } \\
\text { parts of the body }\end{array}$ & $\begin{array}{l}\text { Informing others } \\
\text { about the } \\
\text { approach of the } \\
\text { vehicle body } \\
\text { during } \\
\text { maneuvers } \\
\end{array}$ & $\begin{array}{l}\text { Selection of } \\
\text { materials with the } \\
\text { specified qualities } \\
\text { for different parts } \\
\text { of the vehicle body }\end{array}$ \\
\hline & vehicle engine & $\begin{array}{l}\text { Increasing the } \\
\text { strength and wear } \\
\text { resistance of the } \\
\text { engine parts of the } \\
\text { vehicle, its anti- } \\
\text { corrosion coating }\end{array}$ & $\begin{array}{l}\text { Registration of } \\
\text { psychophysical } \\
\text { reactions of the } \\
\text { driver and others to } \\
\text { various modes of } \\
\text { vibration and noise } \\
\text { during engine } \\
\text { operation }\end{array}$ & $\begin{array}{l}\text { Identification of } \\
\text { dangerous engine } \\
\text { operating modes, } \\
\text { informing the } \\
\text { driver about it }\end{array}$ & $\begin{array}{l}\text { Optimization of } \\
\text { vehicle engine } \\
\text { operating modes } \\
\text { based on the } \\
\text { criterion of } \\
\text { minimizing fuel } \\
\text { consumption, in } \\
\text { particular at start- } \\
\text { up and at idle } \\
\end{array}$ \\
\hline & $\begin{array}{l}\text { Undercarriage } \\
\text { of the vehicle }\end{array}$ & $\begin{array}{l}\text { Increment of the } \\
\text { strength and wear } \\
\text { resistance of the } \\
\text { undercarriage parts } \\
\text { of the vehicle }\end{array}$ & $\begin{array}{l}\text { Recording the } \\
\text { reactions of the } \\
\text { driver's body to } \\
\text { noise while driving }\end{array}$ & $\begin{array}{l}\text { Informing about } \\
\text { the defects in the } \\
\text { tires of vehicles } \\
\text { with damaged } \\
\text { wheels }\end{array}$ & $\begin{array}{l}\text { Adjusting the } \\
\text { pressure in the } \\
\text { wheels of a vehicle } \\
\text { based on the } \\
\text { criterion of } \\
\text { minimizing fuel } \\
\text { consumption when } \\
\text { driving on various } \\
\text { types of roads }\end{array}$ \\
\hline & $\begin{array}{l}\text { Cabin means of } \\
\text { transport }\end{array}$ & $\begin{array}{l}\text { Improving the } \\
\text { strength and wear } \\
\text { resistance of the } \\
\text { materials of the cab of } \\
\text { the vehicle }\end{array}$ & $\begin{array}{l}\text { Registration of } \\
\text { temperature } \\
\text { conditions in the } \\
\text { cab and their impact } \\
\text { on the driver's } \\
\text { condition }\end{array}$ & $\begin{array}{l}\text { Informing the } \\
\text { driver about non- } \\
\text { calculated } \\
\text { temperature } \\
\text { conditions in the } \\
\text { cab }\end{array}$ & $\begin{array}{l}\text { Optimization of } \\
\text { temperature } \\
\text { conditions in the } \\
\text { cab of the vehicle } \\
\text { based on } \\
\text { comfortable } \\
\text { conditions for the } \\
\text { driver }\end{array}$ \\
\hline
\end{tabular}


Strategic Planning of Organizations ' Transition to The Sixth Technological Order in The National Economy

\begin{tabular}{|c|c|c|c|c|}
\hline $\begin{array}{l}\text { The subsystem } \\
\text { of washing the } \\
\text { windows of the } \\
\text { cab of the } \\
\text { vehicle }\end{array}$ & $\begin{array}{l}\text { The increase in wear } \\
\text { resistance and } \\
\text { strength of the parts } \\
\text { of this subsystem of } \\
\text { the vehicle }\end{array}$ & $\begin{array}{l}\text { Registration of the } \\
\text { influence of glass } \\
\text { pollution on the } \\
\text { quality and safety of } \\
\text { the driver's work }\end{array}$ & $\begin{array}{l}\text { Voice and other } \\
\text { information } \\
\text { about the need to } \\
\text { clean the } \\
\text { windows, tips in } \\
\text { emergency } \\
\text { situations }\end{array}$ & $\begin{array}{l}\text { Minimization of the } \\
\text { washing liquid } \\
\text { consumption } \\
\text { provided that the } \\
\text { windows of the } \\
\text { vehicle cab are } \\
\text { sufficiently clean }\end{array}$ \\
\hline $\begin{array}{l}\text { electrical } \\
\text { equipment } \\
\text { means of } \\
\text { transport }\end{array}$ & $\begin{array}{l}\text { Increase of specific } \\
\text { characteristics of } \\
\text { accumulators, } \\
\text { increase of durability } \\
\text { and wear resistance } \\
\text { of elements of electric } \\
\text { equipment of means } \\
\text { of transport }\end{array}$ & $\begin{array}{c}\text { Warning of } \\
\text { dangerous and } \\
\text { illogical behavior of } \\
\text { the driver in } \\
\text { emergency } \\
\text { situations in the } \\
\text { electrical equipment } \\
\text { system } \\
\text { means of transport }\end{array}$ & $\begin{array}{l}\text { Voice prompts, } \\
\text { information and } \\
\text { indication of } \\
\text { emergency } \\
\text { situations in the } \\
\text { electrical } \\
\text { equipment } \\
\text { subsystem } \\
\text { means of } \\
\text { transport }\end{array}$ & $\begin{array}{l}\text { Ensure resource } \\
\text { savings by } \\
\text { optimizing } \\
\text { operating modes to } \\
\text { maximize the } \\
\text { service life of } \\
\text { batteries and other } \\
\text { electrical } \\
\text { equipment } \\
\text { elements }\end{array}$ \\
\hline $\begin{array}{c}\text { Fuel system } \\
\text { means of } \\
\text { transport }\end{array}$ & $\begin{array}{l}\text { Ensuring the growth } \\
\text { of specific } \\
\text { characteristics of fuel, } \\
\text { increasing the wear } \\
\text { resistance, strength of } \\
\text { fuel system parts }\end{array}$ & $\begin{array}{l}\text { Warning of illogical } \\
\text { or dangerous } \\
\text { behavior of the } \\
\text { driver in case of } \\
\text { emergency } \\
\text { situations in the fuel } \\
\text { system }\end{array}$ & $\begin{array}{l}\text { Voice notification } \\
\text { of the driver and } \\
\text { indication of } \\
\text { emergency } \\
\text { situations in the } \\
\text { fuel system }\end{array}$ & $\begin{array}{l}\text { Achieving resource } \\
\text { savings by } \\
\text { optimizing the use } \\
\text { modes and } \\
\text { maximizing the } \\
\text { service life of fuel } \\
\text { system elements }\end{array}$ \\
\hline
\end{tabular}

Source: developed by the author

\section{SOURCES OF FUNDING}

This research received no specific grant from any funding agency in the public, commercial, or not-for-profit sectors.

\section{CONFLICT OF INTEREST}

The author have declared that no competing interests exist.

\section{ACKNOWLEDGMENT}

None.

\section{REFERENCES}

[1] Glushchenko V. V. Scientific theory of technological orders and research of directions of its practical application//Bulletin of Science and Practice. 2020. Vol. 6. no. 4. pp. 488-504.

[2] Glushchenko V. V., Theory of technological orders. - M.: Glushchenko Valery Vladimirovich, 2020. - 80 p.

[3] Minaev V. V., Ivanova B. A. Organizational and economic mechanisms of formation of the strategic programtarget management environment in the Russian economy//Bulletin of Economic Integration. 2012. No. 5. S. 86-91.

[4] Aroshidze A. A. The mechanism of management of sustainable development of an economic entity in the concept of strategic management//Economics and Management in the XXI century: development trends. 2016. No. 29. pp. 41-45. 
[5] Makarova V. I., Yavkina M. G. The mechanism of implementation of strategic planning in the management system of the formation of investment resources of an industrial enterprise//Bulletin of the Samara State University of Economics. 2011. No. 9 (83). pp. 69-74.

[6] Dzyamulich I. I. Mechanism of human capital management for strategic management of innovation-oriented organizations//Innovation and investment. 2013. No. 2. pp. 84-87.

[7] Erygin A.V., Tsvettsykh A.V. Tools for strategic planning of sustainable innovative development of the integrated structure of the military-industrial complex//Problems of mechanical engineering and automation. 2006. No. 4. S. 3-8.

[8] Merzlikina G. S., Tkachenko D. D. Improvement of the strategic planning system in the conditions of uncertainty//Proceedings of the Volgograd State Technical University. 2006. No. 5 (22). pp. 107-110.

[9] Martynov V. V., Startseva Yu. A. Strategic planning of business processes//Bulletin of the Ufa State Aviation Technical University. 2006. Vol. 8. no. 5. p. 108-113.

[10] Glushchenko I. I. The system of strategic management of innovative activity. - Zheleznodorozhny, Moscow region: LLC SPC Krylia, 2006. - 356 p.

[11] Glushchenko I. I. Formation of innovative policy and strategy of the enterprise. - M.: APK and PPRO, 2009. $128 \mathrm{p}$.

[12] Glazyev S. Yu. World economic structures in global economic development//Economics and Mathematical methods. 2016. T. 52. No. 2. S. 3-29

[13] Gurieva L. K. Kontseptsiya tekhnologicheskikh ukladov [The concept of technological structures]. - St. Petersburg, 2004. - No. 10. - pp. 70-75.

http://innov.etu.ru/innov/archive.nsf/779e63082286adbbc325672f003bdcf2/88e58149614c800fc32570 $3000360 \mathrm{bb} 3$

[14] Zagidullina G. M., Sobolev E. A., Krylovsky A. B. Forecasting the structure of the innovative sixth technological order and analyzing the priorities of current industrial development//Proceedings of the Kazan State University of Architecture and Civil Engineering. 2015. No. 1 (31). pp. 182-189.

[15] Orusova O. V., Eliseeva T. S. Development of the strategy of Russia's transition to the sixth technological order//In the collection: The development of modern Russia: problems of reproduction and creation/Collection of scientific papers. Edited by R. M. Nureev, M. L. Albinowski. 2015. S. 82-89.

[16] Kurgansky A. N. Prerequisites for the formation of the sixth technological order in Russia: technological leading branches of the sixth technological order//In the collection: Materials and methods of innovative scientific and practical research and development /collection of articles of the International Scientific and Practical Conference. 2019. P. 37-40.

[17] Fayustov A. A. Prospects for entering the sixth technological order in the light of the implementation of the strategy of scientific and technological development of Russia//In the collection: Priority and promising directions of scientific and technical development of the Russian Federation materials of the II-th All-Russian Scientific and Practical Conference. 2019. S. 54-58.

[18] Grinin L. E., Grinin A. L. Long-term dynamics of changes in the rates of technological growth and the sixth technological order//The book Arrogancia reading on the topic: "The global chaos of the modern world order: the essence, development and ways to overcome it. problems of world reconstruction in the conditions of the triple transition period " / materials of the international scientific and practical conference. Institute of Economics and Management of the Oryol State University named after I. S. Turgenev. Eagle, 2019. P. 211-217.

[19] Kretov S. I. Economic theory at the turn of the sixth technological order//Geopolitical Journal. 2015. No. 4 (11). pp. 70-86.

[20] Kalashnikova Yu. In the Sixth technological order and modern scientific policy of the Russian Federation//Scientific almanac. 2015. No. 8 (10). pp. 201-208.

[21] Glushchenko V. V. Crisisology: General theory of crisis, the way the post-crisis future, criterion approach to research and risk theory of the firm, paradigm of intellectual risk management. - Moscow: IP Glushchenko Valery Vladimirovich, 2011. - $80 \mathrm{p}$.

[22] Glushchenko V. V., Glushchenko I. I. Development of a management solution. Forecasting-planning. Theory of experimental design. - Zheleznodorozhny, Moscow region, LLC SPC "Krylia", 2000. - 400 p.

[23] Glushchenko V. V., Glushchenko I. I. Naukologiya: the task of modernizing science and innovation - Moscow: Glushchenko Irina Ivanovna, 2015. - 116 p.

International Journal of Engineering Science Technologies 
[24] Glushchenko V. V. Problems of the general theory of technological orders / / Kazakhstan Science Journal, 2020, No. 2 (15), pp. 60-74 https://sciencejournal.press/sj/article/view/154/131 (accessed 13.02.2020).

[25] Pogorzhelskaya N. V. Technological structures as a factor of structural development of socio-economic systems//Economics of construction and urban economy. 2017. Vol. 13. No. 1. pp. 93-100.

[26] Glushchenko V. V. Functions and roles of technological orders in the management of technological and socioeconomic development/ / Kazakhstan Science Journal, 2020, No. 3 (16), pp. 80-93. https://sciencejournal.press/sj/article/view/161/138 (accessed 05.03.2020).

[27] GlushchenkoVV 1990 Functional decomposition representation of complex technical systems. News of the USSR Academy of Sciences, Technical Cybernetics2 184-186.

[28] Glushchenko V. V. Tools for the development of a neurotechnological platform in mechanical engineering of the sixth technological order/ / Kazakhstan Science Journal, 2020, No. 1 (14), pp. 44-63.

https://sciencejournal.press/sj/article/view/138/123 (accessed 11.01.2020).

[29] Glushchenko V. V. Formation of the development strategy of the sixth technological order in engineering// Kazakhstan Science Journal, 2021, № 2 (27), pp. . https://sciencejournal.press/sj/article/view/240/198

[30] Glushchenko V. V. System the nature and development of strategy of development of the sixth technological order in the postindustrial world // Modern scientific researches and innovations. 2021. No. 2 [Electronic resource]. URL: http://web.snauka.ru/issues/2021/02/94577 (date accessed: 07.02.2021).

[31] Glushchenko V. V. Neurogeopoliticology and methodological aspects of strategic management of geopolitical risk//Modern scientific research and innovation. 2020. № 4 (108). P. 34.

URL:http://web.snauka.ru/issues/2020/04/91886 (date accessed: 19.04.2020).

[32] Glushchenko V. V., Sheveleva, I. A. Cooperative venture Fund for investment in technological innovation projects//Kazakhstan Science Journal. 2020. Vol. $3 . \quad$ № $11 \quad$ (24). $\quad$ P. 60-75. https://sciencejournal.press/sj/article/view/221/184 (accessed 03.11.2020).

[33] Glushchenko V. V. Scientific theory of teams and strategic management of teams // Bulletin of science and practice. 2020. Vol. 6 No. 4. P. 272-287. https://doi.org/10.33619/2414-2948/53/32 